\title{
Experimental model of the morphological and morphometric aspects of tissue repair in skin wounds submitted to beta radiation emitted by Strontium -90 in rats ${ }^{1}$
}

\author{
Gerson Vilhena Pereira Filho ${ }^{2}$ \\ José Mario Camelo-Nunes ${ }^{3}$ \\ Fabrício Yui ${ }^{4}$
}

\begin{abstract}
Pereira Filho GV, Camelo-Nunes JM, Yui F. Experimental model of the morphological and morphometric aspects of tissue repair in skin wounds submitted to beta radiation emitted by Strontium -90 in rats. Acta Cir Bras [serial online] 2004 Vol 19 Special Edition. Available on URL: http://www.scielo.br/acb.
\end{abstract}

\begin{abstract}
The purperose of this work is tell the use of the experimental model to investigation of the effects of Beta radiation of estroncium-90 for repairing the tissue of wounds made in rats. 48 animals of the lineage EPM-1 Wistar were used, distributed in two groups that received radiation in alternate days (group A) and daily (group B). Each group was divided in four groups of six rats to be analysed in the 3rd, 7th, 14th and 21st day after operation. Two incisions were made in the back of the animal and sutured immediately afterwards; the upper part was irradiated and the lower part used as control. On the dates established the irradiated and control wounds were macroscopically examined and withdrawn for preparation of the histological comparative study in the optical microscope. Following, an morphometrical analysis was performed to count leucocyts, fiberblast and colagen fibers which were submitted to statistical study.
\end{abstract}

KEY WORDS - Models, Animal. Wound healing. Beta radiation. Rats. Histological study.

\section{Introduction}

Ionizing radiation has been used to attempt to control various biological phenomena, including the healing of wounds.

Beta rays are a form of particulate radiation with a negative charge and they cause a number of changes in the tissues through which they pass, notably ionization and energy absorption. These rays cause direct modifications of cell nuclei and indirect modifications of protoplasm. The ionizing radiation can break the bonds of hydrogen or sulphydryls, oxidize compounds, sever bonds within the DNA helix or cause the dimerization of the DNA purine and pyrimidine bases. Cell sensitivity to these effects is higher during the pre-mitotic stage, hence the need for repeated applications of Beta rays, at given intervals, to ensure that a large number of cells is irradiated effectively ${ }^{1}$.

\footnotetext{
1. Research carried out in the Surgical Technique and Experimental Surgery Laboratory of the Surgery Department of the Paulista School of Medicine.

2. Master's Degree and Ph.D. from the Paulista School of Medicine of the Federal University of São Paulo UNIFESP; Head of Plastic Surgery of the ABC Medical School. 
FRIEDELL, THOMAS and KROHMER (1951) established that radioactive Strontium-90 is the best source of beta radiation; they were the first ones to use it. Its half-life is long (28 years), avoiding the need for frequent substitution of the element in the equipment employed. It emits effective energy that penetrates tissues sufficiently. Its impact does not exceed a depth of 8 millimeters but the bulk of its therapeutic effect centers around 3 to 4 millimeters. Furthermore, satisfactory clinical experience with this type of irradiation has been reported in connection with eye diseases ${ }^{2}$.

SETTI (1960) presented the results he obtained from the use of beta radiation emitted by Strontium-90. He experimentally applied it to the left forearm of two patients, in single doses that ranged from 90 to 7200 reps, in order to research skin reactions. He found that erythema manifested itself within the first 24 hours starting with 450 reps. Higher doses produced wheals and vesicles. The reactions receded over 40 days, leaving no sequelae. He also referred to good results using radiation for the treatment of eye diseases ${ }^{3}$.

Beta radiation emitted by Strontium is employed as a complementary post-resection treatment of hypertrophic and keloidal scars, but no clinical or experimental study was found in literature on its effect on the treatment of wounds.

\section{Proposition}

The purpose of this paper is to give an account of an experimental model for investigating the effects of beta radiation emitted by Strontium-90 for repairing the tissue of skin wounds inflicted on rats.

\section{Method description}

The animals were distributed into two groups based on the frequency of irradiation. Each group was subdivided into four other groups for examination on the $3^{\text {rd }}, 7^{\text {th }}, 14^{\text {th }}$ and $21^{\text {st }}$ days after surgery, as follows in TABLE 1.

TABLE 1 - Distribution of the animals into groups based on the frequency of irradiation and time of examination.

Days of observation

№ of

\begin{tabular}{cllllll} 
Group & Irradiation & 3 & 7 & 14 & 21 & Animals \\
\cline { 3 - 5 } A & Alternate Days & 6 & 6 & 6 & 6 & 24 \\
B & Daily & 6 & 6 & 6 & 6 & 24 \\
\hline
\end{tabular}

\section{Animals and experiment environment}

The animals were kept in isolated cages for seven days for adaptation purpose, on a diet of Labina animal feed (manufactured by Purina Nutrimentos Ltda.) and water, freely.

\section{Outline of the experiment}

The animals were anesthetized by inhalation inside a bell jar, within which the atmosphere was saturated with ethyl ether until the animals became unconscious.

During the surgical procedure, the state of anesthesia was maintained with the same anesthetic in partial saturation with air, the animal's head being maintained within a small bell jar. 
Each rat was put into a horizontal decubitus position, belly down, paws fixed to a plank.

Two circular areas with a diameter of $2.5 \mathrm{~cm}$ each had the fur manually removed. Both were on the animal's dorsal region: one near the skull, where the radiation would be applied, and the other one near the tail, for control purposes (FIGURE 1).

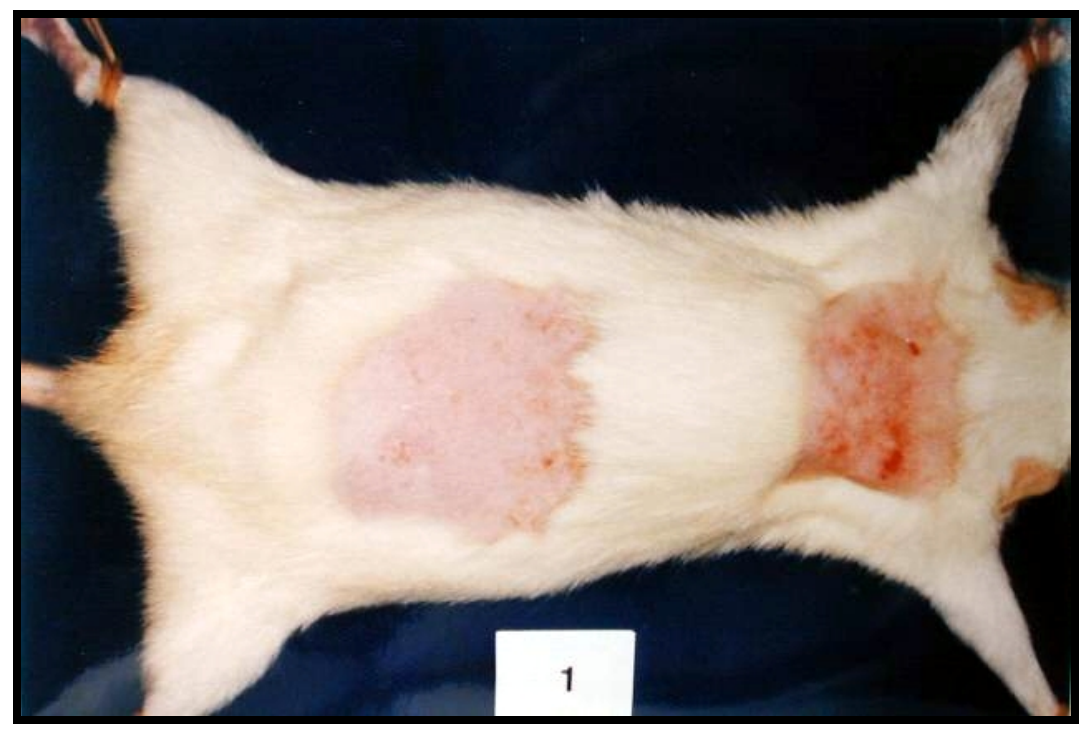

FIGURE 1 - Photograph of a rat, showing the two circular areas on the dorsal region where the fur was removed.

The antisepsis of the two areas was carried out using iodized alcohol at $2 \%$, followed by placement of a fenestrated drape. In each area a $1.5 \mathrm{~cm}$ long incision was made with a 15 blade surgical knife, cutting through the full thickness of the skin (FIGURE 2). Hemostasis was achieved using gauze, through manual pressure applied for roughly three minutes. The skin was sutured with three separate simple stitches using a 6-0 nylon monofilament (FIGURE 3) .

The areas that underwent surgery were not dressed.

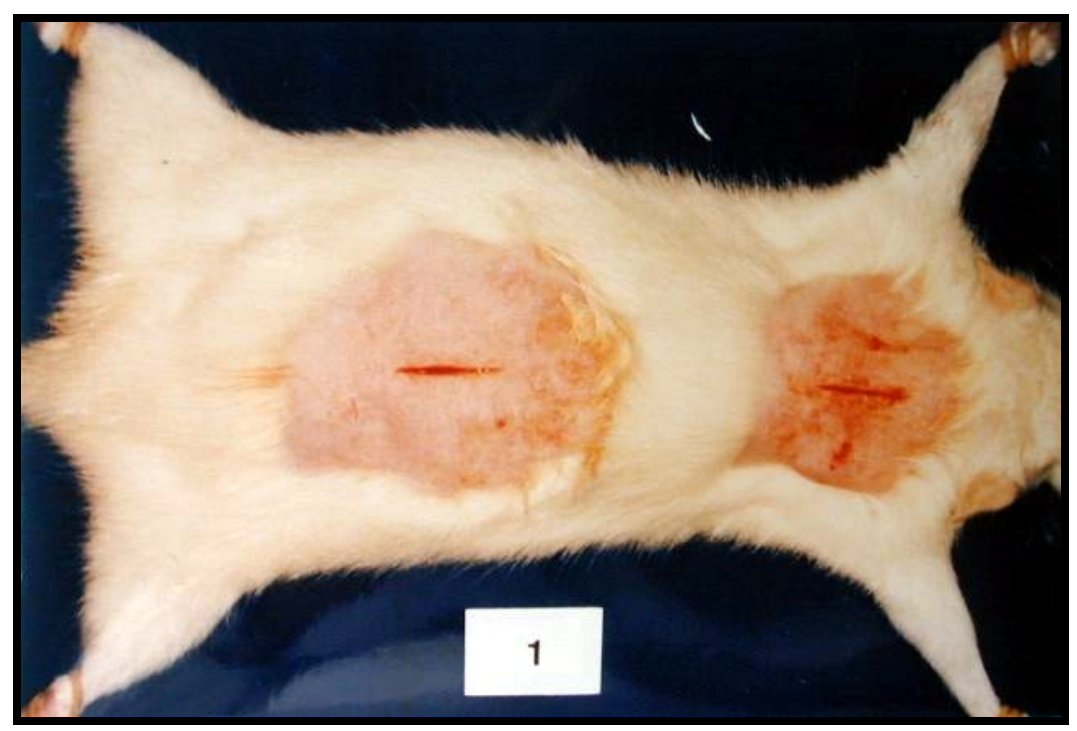

FIGURE 2-Photograph of rat, showing the two incisions. 


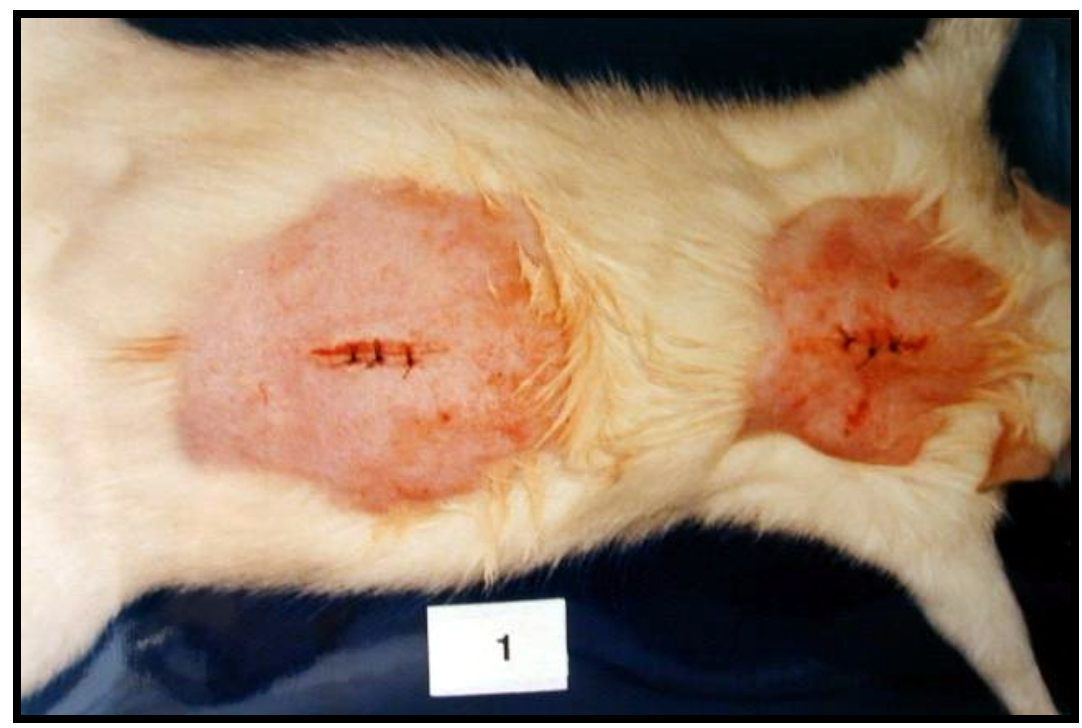

FIGURE 3 - Photograph of rat, showing the two sutured wounds.

\section{Post-surgical period}

Following the surgical procedure, the animals were placed back into their respective cages and were given a diet of animal feed and water similar to the one provided during the period of adaptation. The stitches were removed on the $10^{\text {th }}$ day after surgery.

\section{Irradiation}

24 hours after surgery, the animals were again anesthetized in a bell-jar with ethyl ether vapor and were given their first dose of radiation. For this we used a Strontium-90 plate with a diameter of $1.5 \mathrm{~cm}$ and activity of $50 \mathrm{mci}^{1}$, as measured in October 1985, and a penetration power of 1.54 million electron volts (FIGURE 4).

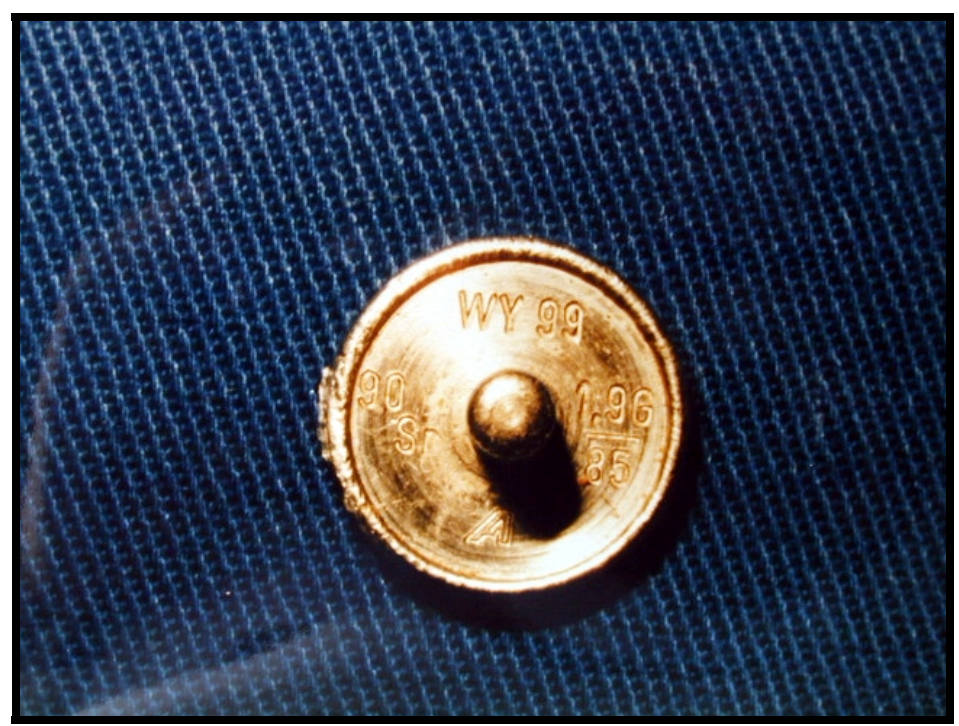

FIGURE 4 - Photograph showing the Strontium-90 plate used to emit beta radiation. 
The dose for each session was $250 \mathrm{cGy}^{2}$, the session consisting of contact of the plaque with the skin for 13.8 seconds. The total maximum dose was 2,500 cGy. We used a protection rod to make the handling of the radioactive material easier. A chronometer was used to measure time. (FIGURE 5).

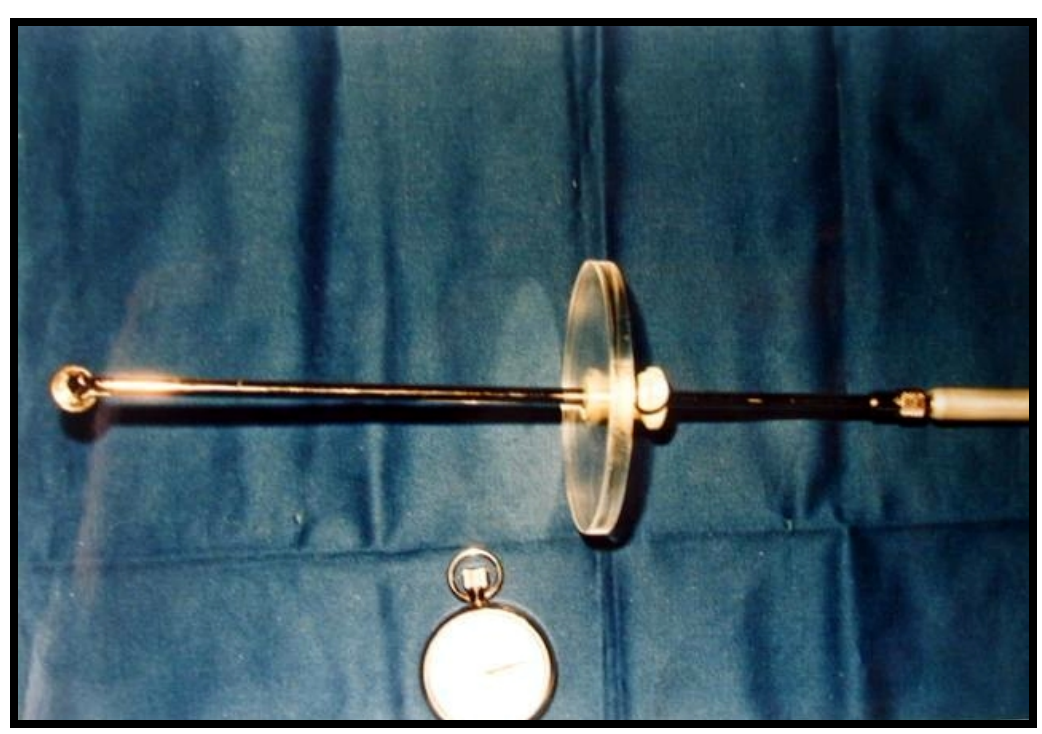

FIGURE 5 - Photograph showing the Strontium-90 plate used for the emission of beta radiation on the end of a protection rod and the chronometer used.

The frequency of irradiation was different in each group. Group A received doses every 48 hours, whereas group B was treated to them every 24 hours. Each subgroup was submitted to doses as follows in TABLE 2.

TABLE 2 - Frequency of irradiation in each group versus time of observation.

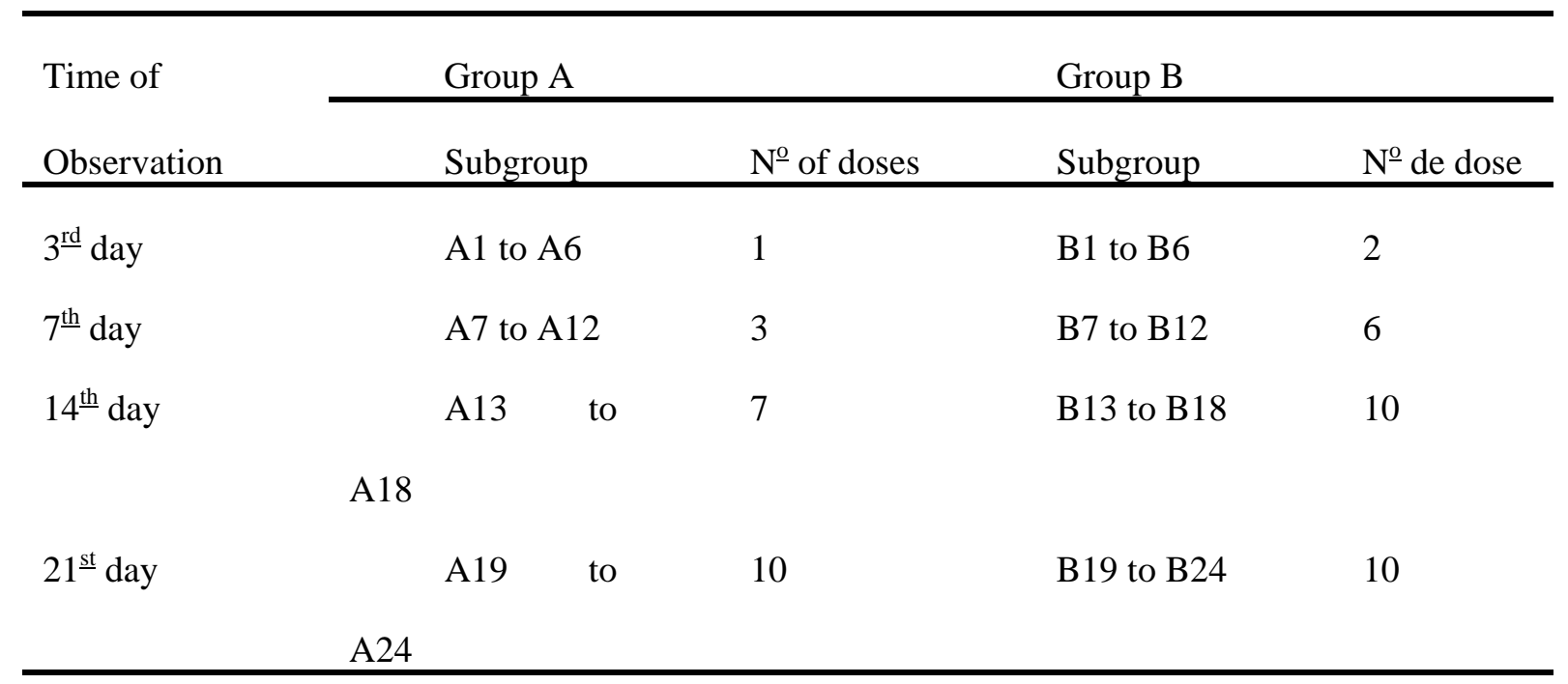




\section{Morphological study}

On the days predetermined for sacrificing the animals, they were first anesthetized inside a bell jar saturated with ethyl ether vapor. Photographs were taken of the irradiated and control areas for macroscopic comparison purposes.

A full thickness skin segment $0.5 \mathrm{~cm}$ long by $1.0 \mathrm{~cm}$ wide was removed from the irradiated and control areas, always including the middle third of the surgical wound (FIGURE 6).

This material was placed in formaldehyde at $10 \%$ for 24 hours and then underwent the standard techniques for embedding in paraffin, after which it was sliced with a microtome into sections 6 micra thick and treated in accordance with the Hematoxylin-Eosin (HE) method and the Masson Trichrome methods (MT).

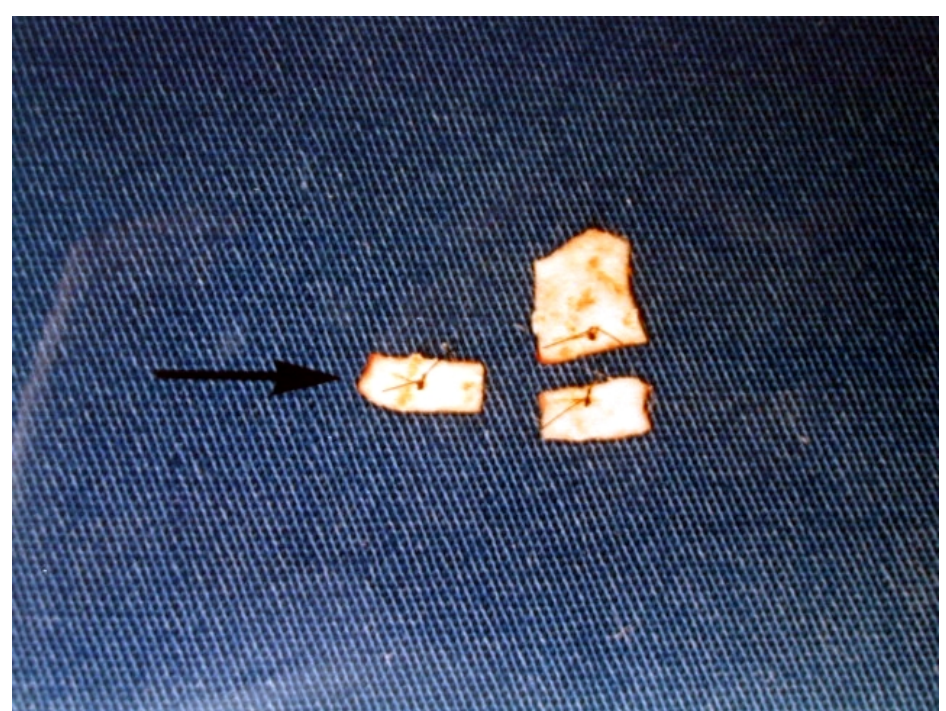

FIGURE 6 - Photograph showing the middle third of the surgical would, dislocated to the left (arrow), which was used for examination under an optical microscope.

The histological incisions were analyzed under a standard optical microscope and the irradiated wounds were compared to the control wounds on the $3^{\text {rd }}, 7^{\text {th }}, 14^{\text {th }}$ and $21^{\text {st }}$ day after surgery.

The morphometric study was carried out using a ZEISS Kpl-10x integrating eye-piece, containing a reticule with 25 geometrically distributed points. This eye-piece was attached to a ZEISS 100x objective (yielding a total magnifying effect of 1,000 diameters). 40 fields were observed on each slide.

Leukocytes, fibroblasts and collagen fibers were counted.

This study was conducted at the Pathological and Histological Anatomy Laboratories of the Paulista School of Medicine.

\section{Perspectives}

Given the doubts surrounding clinical applicability and the scant literature on the subject, the use of this experimental model is put forth as a possibility for the study of the recovery of skin wounds treated with beta radiation emitted by Strontium- 90 .

The experiment represents what is done in common post-resection clinical practice involving hypertrophic and keloidal scars at our Service. 


\section{References}

1. Raper JR, Zirkle RE, Barnes KK - Techniques of external irradiation with Beta rays. In: Zirkle RE. Effects of external beta radiation. 1.ed. New York, McGraw-Hill Book Company, 1951. p.1-41.

2. Fredell HL, Thomas CI, Krohmer JS - An evaluation of the clinical use of a strontium 90 betaray applicator with a review of the underlying principles. Am J Roentgenol Radium Ther. 1954;71:25-39.

3. Setti RI - Atualização do emprego do estrôncio 90 em oftalmologia. Arg Bras Oftamol.. 1961;24:174-83.

4. Baroncelli G, Magno L, Tunesi G - La posizione dello stronzio 90 nella radioterapia di contato: proprietá fisiche, modalitá tecniche d'impiego, indicazioni cliniche. Radiol Med. 1962;48: 635-62.

5. Bishop FW - Comparison of X- and beta-radiation effects in rabbits. In: Blair, HA. - Biological effects of external radiation. 1.ed. New York, McGraw-Hill Book Company, 1954. p.194-203.

6. Elliott R - A method of beta particle treatment. Trans Ophthalmol Soc. 1959;11:32-40.

7. Fukuyama K, Bernstein IA, Curtis AC - Effect of beta-radiation on mitotic activity in the skin of the young rat. J Invest Dermatol. 1959;32:39-42.

8. Horwitz H, Haybittle JL - Whole body superficial irradiation with strontium 90 beta rays: a report of cases treated with a moving couch technique. Br J Radiol . 1960;33:440-6.

9. Lushbaugh CC, Storer JB, Hale DB - Experimental acute radiodermatitis following beta radiation: I. Its pathogenesis and repair. Cancer. 1953;6:671-7.

10. Prado MAS - Aspectos morfológicos e morfométricos do processo de reparação da pele de ratos albinus, após ação dos raios X. São Paulo, 1981. 48p. [Master’s Degree Thesis - Escola Paulista de Medicina]

11.Raper JR, Barnes KK - Gross effects of total surface Beta irradiation. In: Zirkle RE. - Effects of external beta radiation. 1.ed. New York, McGraw-Hill Book Company, 1951. p.77-109.

12.Simões MJ, Uzuian A, Mora OA, Sasso WS - Aspectos ultra-estruturais do processo de reparação da pele de ratos albinus. Rev Paul Med.1985;103:123-6.

13. Snider RS, Raper JR - Histopathological effects of single doses of total surface beta radiation on mice. In: Zirkle RE. - Effects of external beta radiation.1 ed. New York, McGraw-Hill Book Company, 1951. p.152-78.

Pereira Filho GV, Camelo-Nunes JM, Yui F. Modelo experimental dos aspectos morfológicos morfométricos da reparação tecidual de feridas cutâneas submetidas à radiação beta do Estrontio90. Acta Cir Bras [serial online] 2004 Vol 19 Edição Especial. Disponível em URL: http://www.scielo.br/acb.

RESUMO - O objetivo deste trabalho é relatar o uso do modelo experimental para investigação dos efeitos da radiação Beta do Estrôncio-90 no processo de reparação tecidual de feridas provocadas em ratos. Utilizamos 48 animais da linhagem EPM-1 Wistar, distribuídos em dois grupos que receberam a radiação em dias alternados (Grupo A) e diariamente (Grupo B). Cada grupo foi subdividido em quatro, cada um com 6 ratos, para estudo no $3^{\circ}, 7^{\circ}, 14^{\circ}$ e $21^{\circ}$ dias de pósoperatório. Realizou-se duas incisões no dorso de cada animal, suturou-se em seguida, sendo que a de situação cranial foi irradiada e a caudal serviu para controle. Nas datas determinadas, as feridas controle e irradiada foram observadas macroscopicamente e retiradas para preparo do estudo histológico comparativo ao microscópico óptico. Realizou-se em seguida, análise morfométrica para contagem de leucócitos, fibroblastos e fibras colágenas, submetidos a estudo estatístico.

DESCRITORES - Modelos animais. Reparação tecidual. Radiação beta. Ratos. Estudo histológico. 
Conflito de interesse: nenhum

Fonte de financiamento: nenhum

Correspondence:

Fabrício Yui

UNIFESP-EPM, Plastic Surgery Division, Surgery Division

Rua Napoleão de Barros, 715, 4o andar

CEP: 04024-900 São Paulo - SP

Tel: (11) 55764118 Fax: (11) 55716579

sandra.dcir@epm.br

fabrício@yui.com.br 